\title{
LETHAL EFFECTS OF 2,2-DICHLOROVINYL DIMETHYL PHOSPHATE (DDVP) ON FINGERLING AND JUVENILE CLARIAS GARIEPINUS (BURCHELL, 1822)
}

\author{
Isac Tunde Omoniyi*, Kazeem Lanre Adeogun, Samuel Olubodun Obasa \\ Department of Aquaculture and Fisheries Management, Federal University of Agriculture, Abeokuta, Nigeria tel. +2348038093831 \\ * Corresponding Author, E-mail: itomoniyi@yahoo.com
}

\section{ARTICLE INFO}

Received: $28^{\text {th }}$ April 2012

Received in revised form:

$15^{\text {th }}$ January 2013

Accepted: $28^{\text {th }}$ February 2013

Available online: $2^{\text {th }}$ March 2013

\begin{abstract}
This study investigated the lethal toxicity of 2,2-dichlorovinyl dimethyl phosphate (DDVP) on African mud catfish, Clarias gariepinus fingerlings (mean weight $7.02 \pm 2.56 \mathrm{~g}$ ) and juveniles (mean weight $13.54 \pm 1.46 \mathrm{~g}$ ) in a static renewable bioassay. DDVP, also known as Dichlorvos is an organophosphate pesticide. Each treatment in the lethal test was in triplicates with bioassay media concentrations (fingerlings: 0, 250, 275, 300, 325 $\mu \mathrm{gL}^{-1}$ ) and (juveniles: $0,400,450,500,600 \mu \mathrm{gL}^{-1}$ ). Data on fish mortality as well as the physico-chemical parameters (temperature, $\mathrm{pH}$, dissolved oxygen and electrical conductivity, EC) of water were collected and subsequently subjected to a one way analysis of variance (ANOVA) at 5\% probability level. Duncan Multiple Range Test (DMRT) was used to separate differences between means. The median lethal concentration $\left(\mathrm{LC}_{50}\right)$ and median lethal time $\left(\mathrm{LT}_{50}\right)$ were determined by probit analysis. The water quality parameters of the treatment tanks showed no significant difference with those of the control except for conductivity and $\mathrm{pH}$. Behavioural responses in the fishes included erratic and uncoordinated swimming which were observed to be more pronounced in the juveniles. Bleached body was the only external change observed and this was more pronounced in the fingerlings. The $96-\mathrm{hr} \mathrm{LC}_{50}$ for fingerlings and juveniles were 275.2 and $492.0 \mathrm{\mu gL}^{-1}$ respectively. The $\mathrm{LT}_{50}$ values for fingerlings were 48.10 and $7.77 \mathrm{hrs}$ for concentrations 250 and $325 \mu \mathrm{gL}^{-1}$ respectively; while those of juveniles were 25.54 and $5.34 \mathrm{hrs}$ for 400 and $600 \mu \mathrm{gL}^{-1}$ respectively. The results indicated that DDVP was 1.79 times more toxic to the fingerlings than the juveniles.
\end{abstract}

Keywords:

Dichlorvos, Toxicity, Clarias

gariepinus, $\mathrm{LC}_{50} \mathrm{LT}_{50}$ markets. However, fish populations in water bodies are susceptible to environmental impacts caused by the introduction of exotic species, industrial wastes, oil spills, pesticides and other agents that directly affect the ecology and the survival of species. Pesticides contain poisonous substances (toxicants) that distort water quality and impose physiological stress on biotic community of the water body which
Fish is the cheapest animal protein source in Nigeria because of its availability, palatability and health provision (Fawole et. al., 2007). Agbon et. al. (2010) also remarked that fish is a heavily traded food commodity in the country and it is becoming a fastest growing agricultural item in international 
is the home of fish (Asonye et. al., 2007).

In Nigeria, agrochemicals that contain such pesticides, especially chlorinated hydrocarbons and the organophosphates, are routinely employed as part of the integrated farming practice to protect crops and animals from insects, weeds and diseases (Fafioye et. al., 2001). Thus, toxicity tests become imperative to estimate potential hazards as part of risk assessment protocols in agriculture, especially in fish farming. Toxicity tests are performed for the specific purpose of predicting what biological functions would be perturbed by the toxicant exposure or explicitly quantify the effect of a toxicant on the health of an organism (Omoniyi et. al., 2002; Omoregie et. al., 2009). A number of factors influence the response of organisms to toxicity tests. These factors include age, disease, water quality, stage in life history/cycle, pollutant interaction, nutrient status, reproductive stage and species interactions. Different species of organisms vary in their vulnerability to specific pollutant (Umar et. al., 2010). Joshi et. al. (2002) reported that the most adverse effect of organophosphate pesticides (Chloropyrifos) on Tilapia guineensis were observed in fish exposed to $0.1 \mathrm{mgL}$ ${ }^{1}$. Omitoyin et. al. (2006) reported that $\mathrm{LT}_{50}$ was 26 and $67 \mathrm{hrs}$ in $1.8 \mathrm{mgL}^{-1}$ and $0.8 \mathrm{mgL}^{-1}$ for Clarias gariepinus when exposed to Lindane. Idi-Ogede et. al. (2012) reported the $96-\mathrm{hr} \mathrm{LC}_{50}$ value of $8.20 \mathrm{mgL}^{-1}$ on exposure of C. gariepinus to Sniper 1000EC (an organophosphate pesticide). Fish is a non-target organism to the use of agricultural chemicals but it is affected through loss of habitat and food supply. Dichlorvos also known as DDVP (2,2-dichloro-vinyl dimethyl phosphate) is imported, marketed and used by farmers in Nigeria (Fawole et. al., 2007). Therefore, this study was conducted to investigate the lethal toxicity of Dichlorvos on a commercially important farmed fish species as C. gariepinus under laboratory conditions. The study is necessary to secure additional knowledge on the toxicology and the use of the pesticide by agriculturists, especially fish farmers in the country.

\section{MATERIALS AND METHODS}

The pesticide used is a Dichlorvos with a chemical formula of 2,2-dichlorovinyl dimethyl phosphate, $\mathrm{C}_{4} \mathrm{H}_{7} \mathrm{Cl}_{2} \mathrm{O}_{4} \mathrm{P}$ (DDVP). It is a contact acting and fumigant pesticide for the control of a wide range of insects. It is an emulsifiable concentrate (EC) containing $1000 \mathrm{mgL}^{-1}$ DDVP. It was purchased from a reputable agrochemical stores in Abeokuta, Ogun State, Nigeria.

Both the fingerlings and juveniles of $C$. gariepinus were procured in batches from a reputable commercial fish farm in Abeokuta. The fish were transported in polythene bags half filled with five litres of dechlorinated tap water (from storage tank) to the laboratory where they were held in a large water bath of $160 \mathrm{~L}$ capacity for acclimation over 14 days. The fish were not fed in the first two days of acclimation after which they were fed 3\% body weight with Coppens fish feed containing 45\% crude protein as described by Omoniyi et. al. (2002). The water in the bath was replenished with dechlorinated municipal tap water and uneaten food and faecal matter were siphoned out. A total mortality of $2 \%$ was recorded during the acclimation. Feeding of fish was stopped 24 hours before commencement of the experiment.

Four concentrations $\left(250,275,300,325 \mu \mathrm{gL}^{-1}\right)$ of the bioassay media were prepared and a control $\left(0 \mu \mathrm{gL}^{-1}\right)$ was maintained. The volume of each test solution in fifteen $60 \times 30 \times 20 \mathrm{~cm}$ glass aquaria was 20 litres for all treatments in triplicates. Ten acclimated fingerlings (mean weight $7.02 \pm 2.56 \mathrm{~g}$; total length $6.2 \pm 1.4 \mathrm{~cm}$ ) were randomly introduced into each aquarium for the acute bioassay test starting from the control. The fish were not fed during the 96-hour duration of the acute toxicity experiment as described by Omoniyi et. al. (2002) and Omoregie et. al. (2009). Similar procedures were used for the juveniles (mean weight $13.54 \pm 1.46 \mathrm{~g}$; total length $14.4 \pm 2.0$ $\mathrm{cm}$ ) with different concentrations of 400, 450, 500, $600 \mathrm{\mu gL}^{-1}$ solutions and a control maintained.

The physical and chemical parameters of the media including water temperature, hydrogen ion concentration $(\mathrm{pH})$, dissolved oxygen (DO) and water conductivity were monitored and recorded. The behavioural responses of the test fish to the toxicant at different concentrations were observed and recorded. Fish were confirmed dead when they did not react to touch stimulus. The fish were also observed for any external changes in the body while in the test media.

Data from physico-chemical parameters of the test media were subjected to one way analysis of variance (ANOVA) at $5 \%$ probability level. Duncan Multiple Range Test (DMRT) was used to determine the difference between means of treatment when ANOVA showed significance. The median lethal toxicity $\left(\mathrm{LC}_{50}\right)$ and median lethal time $\left(\mathrm{LT}_{50}\right)$ were determined using probit analysis as described by Wardlaw (1985).

\section{RESULTS}

The temperature and dissolved oxygen content (DO) of the test water fluctuated slightly during the toxicity test as shown in Table 1. During the toxicity 
Table 1. Mean values of physico-chemical parameters of different concentrations during acute toxicity

\begin{tabular}{ccccc}
\hline \hline Concentration $\left(\mu \mathrm{gL}^{-1}\right)$ & $\mathrm{DO}\left(\mathrm{mgL}^{-1}\right)$ & Temperature $\left({ }^{\circ} \mathrm{C}\right)$ & $\mathrm{pH}$ & $\begin{array}{c}\text { Conductivity } \\
\left(\mathrm{uScm} \mathrm{C}^{-1}\right)\end{array}$ \\
\hline 0 & $6.24 \pm 0.04^{\mathrm{a}}$ & $26.38 \pm 0.05^{\mathrm{a}}$ & $6.59 \pm 0.03^{\mathrm{a}}$ & $146.27 \pm 0.08^{\mathrm{a}}$ \\
250 & $6.14 \pm 0.24^{\mathrm{a}}$ & $26.68 \pm 0.25^{\mathrm{a}}$ & $6.49 \pm 0.33^{\mathrm{a}}$ & $150.52 \pm 0.02^{\mathrm{b}}$ \\
275 & $6.18 \pm 0.02^{\mathrm{a}}$ & $26.77 \pm 0.23^{\mathrm{b}}$ & $6.34 \pm 0.02^{\mathrm{b}}$ & $160.28 \pm 0.24^{\mathrm{c}}$ \\
300 & $6.16 \pm 0.12^{\mathrm{a}}$ & $26.76 \pm 0.12^{\mathrm{b}}$ & $6.16 \pm 0.05^{\mathrm{c}}$ & $168.22 \pm 0.28^{\mathrm{d}}$ \\
325 & $6.13 \pm 0.04^{\mathrm{a}}$ & $26.76 \pm 0.05^{\mathrm{b}}$ & $6.09 \pm 0.02^{\mathrm{d}}$ & $170.39 \pm 0.12^{\mathrm{e}}$ \\
\hline \hline
\end{tabular}

Values with the same alphabets along the column were not significantly $(p>0.05)$ different

test, DO ranged between 6.13 and $6.24 \mathrm{mgL}^{-1}, \mathrm{pH}$ from 6.09 to 6.59 ; temperature from 26.38 to $26.77^{\circ} \mathrm{C}$ and conductivity from 146.27 to $170.39 \mu \mathrm{Scm}^{-1}$. The water quality parameters of the treatment tanks varied significantly $(p<0.05)$ with those of the control except for DO.

DDVP induced severe behavioural responses in the two stages of the fish. Behavioural responses observed were lateral and upward bending of the body, erratic and spiral swimming, spontaneous air gulping at different rates, sudden quick movement/jumping, respiratory distress and state of calmness.

Bleached body with lesions was the only external change observed in the test fish and this was more in the fingerlings at higher concentrations. All the fish in the control medium survived during the toxicity experiment, while mortalities were observed in all treatments as shown in Tables 2 and 3.

Table 2. Mortality in the three replicates of Clarias gariepinus fingerlings in different concentrations of DDVP at 96-hr period

\begin{tabular}{ccccc}
\hline \hline $\begin{array}{c}\text { Concentration } \\
\left(\mu \mathrm{gL}^{-1}\right)\end{array}$ & \multicolumn{3}{c}{ Replicates } & $\begin{array}{c}\text { Mortality } \\
(\%)\end{array}$ \\
\cline { 2 - 4 } & 1 & 2 & 3 & 0.00 \\
250 & 0 & 0 & 0 & 13.33 \\
275 & 2 & 0 & 2 & 60.00 \\
300 & 7 & 5 & 6 & 80.00 \\
325 & 7 & 8 & 9 & 96.67 \\
\hline \hline
\end{tabular}

Table 3. Mortality in the three replicates of Clarias gariepinus juvenile in different concentrations of DDVP at $96-\mathrm{hr}$ period

\begin{tabular}{ccccc}
\hline \hline $\begin{array}{c}\text { Concentration } \\
\left(\mu \mathrm{gL}^{-1}\right)\end{array}$ & \multicolumn{3}{c}{ Replicates } & $\begin{array}{c}\text { Mortality } \\
(\%)\end{array}$ \\
\cline { 2 - 4 } & 1 & 2 & 3 & 0.00 \\
400 & 0 & 0 & 0 & 20.00 \\
450 & 1 & 1 & 3 & 33.33 \\
500 & 3 & 3 & 4 & 70.00 \\
600 & 4 & 7 & 10 & 93.33 \\
\hline \hline
\end{tabular}

With respect to mortality, all treatments varied significantly $(p<0.05)$ from the control. Mucus was copiously observed on the gills of the dead fish in all treatments except the control which recorded no mortality. The probit mortality curves are shown in Figures 1 and 2 for the fingerlings and juveniles respectively. The curves were subjected to regression analysis and the $96-\mathrm{hr} \mathrm{LC}_{50}$ of DDVP were estimated to be $275.2 \mu \mathrm{gL}^{-1}$ and $429.0 \mu \mathrm{gL}^{-1}$ for the fingerling and juvenile respectively.

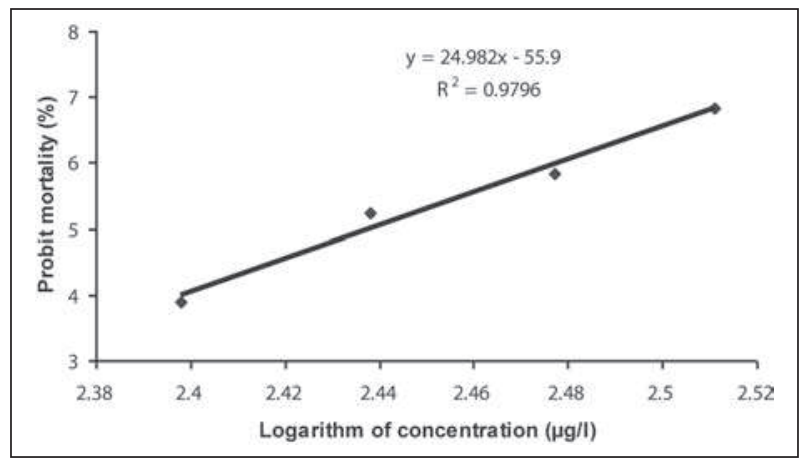

Fig 1. Linear relationship between logarithm of concentration and percentage mortality of Clarias gariepinus fingerling exposed to different acute concentrations of DDVP

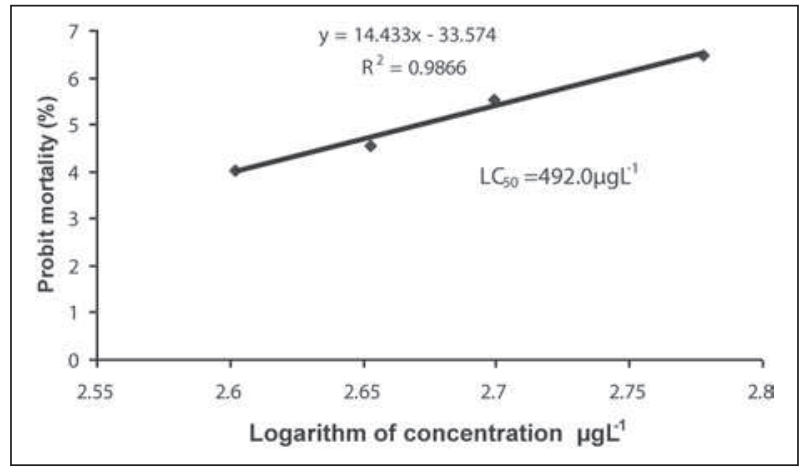

Fig 2. Linear relationship between logarithm of concentration and percentage mortality of Clarias gariepinus juvenile exposed to different acute concentrations of DDVP 
The linear relationship of $96-\mathrm{hr} \mathrm{LT}_{50}{ }^{-}$probity mortality was estimated to be 48.10 and $7.77 \mathrm{hrs}$ for concentrations 250 and $325 \mu \mathrm{L}^{-1}$ in fingerlings, while the juvenile fish were 25.94 and $5.34 \mathrm{hrs}$ for concentrations at 400 and $600 \mu \mathrm{gL}^{-1}$ respectively. These time-probity mortality curves are shown in Figures 3 and 4 for fingerlings and juveniles respectively. The calculated toxicity severity of the pesticide on the two developmental stages of $C$. gariepinus revealed that DDVP was 1.79 times more toxic to the fingerlings than the juvenile stage.

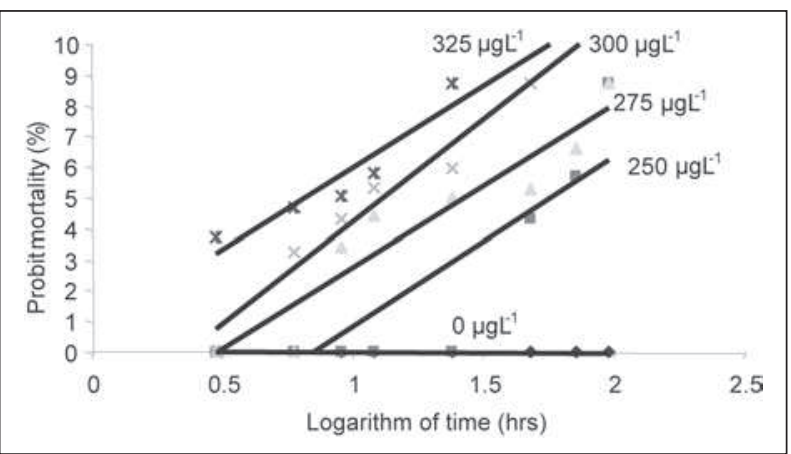

Fig 3. Linear relationship between logarithm of time and probit mortality in different concentration of Clarias gariepinus fingerling exposed to acute concentrations of DDVP

\section{DISCUSSION}

The lethal toxicity test showed that all the fish in the control medium survived while mortalities were observed in all treatments. The mortality increased with increasing concentration of the toxicant in water showed a dose-response relation which has been reported by many authors including Agbon et. al. (2002), Omoregie et. al. (2009) and Umar et. al. (2010). Mucus observed on the gills of the dead fish might be responsible for the mortality recorded in this study. Omoniyi et. al. (2002) reported that accumulation of mucus on gills reduces respiratory activity because of the inability of the gill surfaces to actively carry out gaseous exchange, thus the recorded mortalities. The result of the water quality of the media was within the optimal range recorded by FAO (2000) and Omoregie et. al. (2009) as requirements for C. gariepinus culture implied that the parameters did not seem to influence the toxicity of the pesticide to the test fish. Mortality observed during the acclimation must have been due to stress at handling and transportation from the fish farm to the experimental laboratory. Omoniyi et. al. (2002) made similar observations.

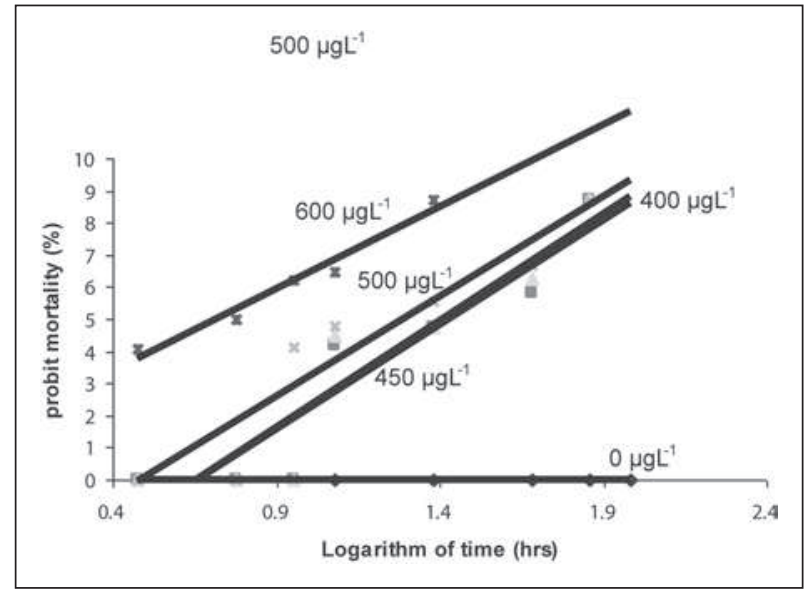

Fig 4. Linear relationship between logarithm of time and probit mortality of juvenile exposed to different acute concentrations of DDVP

The fish exhibited stressful behaviours which were higher as the concentration of toxicant increased. There was a gradual decrease with time until a state of calmness, which was subsequently followed by death. A similar pattern of behaviour was reported by Fafioye et. al. (2001) on C. gariepinus and Rahman et. al. (2002) on C. punctatus. The observed restlessness and uncoordinated swimming in bioassay media might be due to the effect of trichlorvos which is a stimulant in the pesticide. Dichlorvos was specifically identified to inhibit cholinesterase enzymes (Umar et. al., 2010). It could bind on to acetylcholine receptors in the nervous system thus causing the excitation and the resultant jumping and restlessness. Bleached bodies with lesions were indicative of damage caused by DDVP. Fafioye et. al. (2001) reported that skin abnormalities such as lesions could expose the fish flesh to various other diseases. Omoregie et. al. (1990) had made a similar observation.

The $\mathrm{LC}_{50}$ of DDVP to the fingerling stage of $C$. gariepinus was lower than that of the juvenile but the value was still higher than the $96-\mathrm{hr} \mathrm{LC}_{50}$ values reported for other organophosphate pesticides (Omonregie et. al., 1990; Rahman et. al., 2002 and Omitoyin et. al., 2006). The values of $\mathrm{LC}_{50}$ and $\mathrm{LT}_{50}$ on both developmental stages of $C$. gariepinus indicated that the pesticide exerted lethal effects more on the fingerling than the juveniles. The result even showed 1.79 times more toxicity to the fingerling than the juveniles probably due to the physiological and structural fragility differences of the two stages.

The abnormalities in behaviour and mortalities of $C$. gariepinus as a result of exposure to the DDVP pesticide under laboratory conditions suggest that the use of Dichlorvos by farmers, fisherfolk and other Nigerians be banned to preserve the lives of 
non-target organisms, especially the fishes in the water bodies. This pesticide is highly poisonous to fish and its public awareness should be enhanced in the country.

\section{Sažetak}

\section{LETALNO DJELOVANJE 2,2-DIKLOROVINIL DIMETIL FOSFATA (DDVP) NA MLAĐ I MLADUNCE VRSTE CLARIAS GARIEPINUS (BURCHELL, 1822)}

Ovim istraživanjem proučavano je letalno djelovanje 2,2-diklorovinil dimetil fosfata (DDVP) za mlađ (srednja masa 7,02 $\pm 2,56 \mathrm{~g}$ ) i mladunce (srednja masa $13,54 \pm 1,46 \mathrm{~g}$ ) afričkog soma Clarias gariepinus u statičnoj obnovljivoj bioanalizi. DDVP (Dichlorvos) je organofosforni pesticid. Svaki tretman letalnog djelovanja vršio se u tri ponavljanja s testnim koncen-

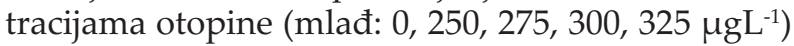
i (mladunci: 0, 400, 450, 500, $600 \mu \mathrm{gL}^{-1}$ ). Prikupljani su podaci o smrtnosti ribe kao i fizikalno-kemijski parametri vode (temperatura, $\mathrm{pH}$, otopljeni kisik $\mathrm{i}$ električna provodnost, EC) te se potom primjenjivala jednosmjerna analiza varijance (ANOVA) s 5\% vjerojatnosti. Korišten je Duncan Multiple Range Test (DMRT) kako bi se razdvojile razlike između srednjih vrijednosti. Srednja letalna koncentracija $\left(\mathrm{LC}_{50}\right)$ i srednje vrijeme smrtnosti $\left(\mathrm{LT}_{50}\right)$ određeni su probit analizom. Parametri kvalitete vode bazena nisu pokazivali značajnu razliku od kontrolnih, osim za provodljivost i $\mathrm{pH}$. Ponašanje riba se očitovalo $\mathrm{u}$ nepravilnom i nekoordiniranom plivanju koje je bilo naglašenije kod mladunaca. Izbijeljeno tijelo je jedina uočena vanjska promjena, a bila je naglašenija kod mlađi. 96-satne vrijednosti LC $_{50}$ za mlađ i mladunce iznosile su 275,2 $\mathrm{ggL}^{-1}$, odnosno $492,0 \mu \mathrm{gL}^{-1}$. Vrijednosti $\mathrm{LT}_{50}$ za mlad su bile 48,10 i 7,77 sati za koncentracije $250 \mu \mathrm{gL}^{-1}$, odnosno 325 $\mu \mathrm{gL}^{-1}$; dok su za mladunce bile 25,54 i 5,34 sati za $400 \mu \mathrm{gL}^{-1}$, odnosno $600 \mu \mathrm{gL}^{-1}$. Rezultati su pokazali da je DDVP 1,79 puta više toksičan za mlađ nego za mladunce.

Ključne riječi: Dichlorvos, toksičnost, Clarias gariepinus, $\mathrm{LC}_{50}, \mathrm{LT}_{50}$

\section{REFERENCES}

Agbon, A. O., I. T. Omoniyi and Teko, A. A. (2002): Acute toxicity of tobacco (Nicotiana tobaccum) leaf dust on Oreochromis niloticus and haematological changes resulting from sub-lethal exposure. Journal of Aquatic Sciences, 17(1):5-8.
Agbon, A. O., I. T. Omoniyi, F. I. Adeosun, W. O. Abdul and C. A. Agbon (2010): Fish Trading: A tool for socio-economic enhancement and poverty alleviation. In: Ansa, E. J., Fashina-Bombata, H. A. and Ndimele, P. E (eds.). proceeding of the $25^{\text {th }}$ Annual Conference \& Fair of the Fisheries Society of Nigeria (FISON). Pp 564-568.

Asonye, C. C., Okolie, N. P., Okenwa, E. E. and Iwuanyawu, U. G. (2007): Some physic-chemical characteristics and heavy metal profiles of Nigerian rivers, streams and waterways. African Journal of Biotechnology, 6(5): 617-624.

Fafioye, O. O., Adeogun, O. A., Olayinka, E. A. and Ayoade, A. A. (2001): Effect of sub-lethal concentrations of lead on growth of Clarias gariepinus. Nigerian Experimental Biology, 5(1): 61-68.

FAO (2000): Manuals of methods in aquatic environment Research. Part 9.analysis of metals and organochlorines in fish. Fish Technical Paper 212.

Fawole, O. O., Ogundiran, M. A., Ayandiran, T. A. and Olagunju, O. F. (2007): Proximate and mineral composition in some selected freshwater fishes in Nigeria. Journal of Food Safety, 9: 52-55.

Idi-Ogede, A.M.(2012): Toxicity of 2,3-Dichlorovinyl Dimethyl Phosphate (Sniper 1000EC) in Clarias gariepinus and Oreochromis niloticus under laboratory conditions. Ph.D Thesis, Federal University of Agriculture Abeokuta, Nigeria. 237pp.

Joshi, P. K., Harish, D. and Bose, M. (2002): Effect of Lindane and Malathion exposure to certain blood parameters in a freshwater teleost fish, Clarias batrachus. Pollution Resources, 21(1): 55-57.

Omitoyin, B. O., Ajani, E. K. and Fajimi, A. O. (2006): Toxicity of Gramoxone (Paraquat) to juvenile African catfish, Clarias gariepinus (Burchell, 1822). American-Euroasian Journal of Agriculture and Environmental Sciences, 1(1): 26-30.

Omoniyi, I. T., Agbon, A. O. and Sodunke, S. A. (2002): Effect of lethal and sub-lethal concentrations of tobacco (Nicotiana tobaccum) leaf dust extract on weight and haematological changes in Clarias gariepinus (Burchell). J. Appl. Sci. Environ. Mgt., 6(2): 37-41.

Omoregie, E., Malachy, N. O., Ajino, I., Romanus, I. and Kazimierz, W. (2009): Effect of single super-phosphate fertilizer on survival and respiratory dynamics of Oreochromis niloticus. Acta Ichthyological et Piscatoria, 39(2): 103-110

Omoregie, E., Ufodike, E. B. C and Keke, I. (1990): Tissue chemistry of Oreochromis niloticus exposed to sub-lethal concentrations of Gammalin 20 and Acetellic 25EC. Journal of Aquatic Sciences, 5: 33-36. 
Rahman, M. Z., Hossain, Z., Mollaqh, M. F. A. and Ahmed, G. U. (2002): Effect of Diazinon 60EC on Testudineus (C. punctatus and B. gonionotus). The ICLARM Quarterly, 25(2): 8-12

Umar, M., Stephen, S. H., Abdullahi, M. and Garba, M. (2010): Dichlorvos concentrations in locally formulated pesticide (Ota-piapia) utilized in Northeastern Nigeria. Scientific Research and Essay, 5(1): 049-054.

Wardlaw, A. C. (1985): Practical Statistics for Environmental Biologists. John Wiley \& Sons. New York USA. 290pp. 